\title{
How have the restrictions linked to COVID-19 affected the inner-tourism in Russia
}

\author{
Elena Priss ${ }^{1 *}$, and Alexey Chukhno ${ }^{1}$ \\ ${ }^{1}$ Don State Technical University, Gagarin square 1, Rostov-on-Don, 344000, Russia
}

\begin{abstract}
Covid-19 has changed tourism significantly. Numerous research shows how various factors will affect travel after COVID-19. No doubt that tourism has become a major global industry with an annual average growth rate of $4-5 \%$. It also creates $8 \%$ of the global GDP and $10 \%$ of employment. Yet it is also very vulnerable to crises of different origin such as natural disasters, epidemics, economic crises, political crises, terror, etc. Because tourism product (e.g. hotel beds, airline seats, restaurant tables, guide services) is perishable, unlike physical goods, they cannot be stored for future use. Past crises with few exceptions (e.g. 2008 Financial Crisis, 2014 Financial Crisis, the terroristic attack of airplane in Cairo 31st of October, 2015) had regional impacts and their global impact on tourism volume was limited. Yet, taking into account the speed and impact, Covid-19 is the most serious crises tourism industry has ever faced. This crisis is estimated to have a seven time larger impact on tourism than the 2008 Financial Crises. The effects of Covid-19 are expected to extend for two years and result in a decrease of $39-50 \%$ in global tourism volume. Tourism industry is expected to recover to 2019 pre-crises levels not before 2023.
\end{abstract}

\section{Introduction}

Tourism is among the first and most severely affected industries from Covid-19. The first response to pandemic was to close the borders and limit human mobility. Moreover tourism demand is not based on a physical need and can be postponed. The recovery is expected to start form domestic tourism and continue with recovered destinations which were usually first affected (e.g. Far East, Europe). Considering that the high season in Summer 2020 was already lost, the great expectations were primary targeted on September 2020 mostly to be the third age group, who are retired, have more leisure time and stable income. Yet, one should also consider that these travelers are also among the risk group for Covid-19. Hence sanitation and social distance are off primary concern in product design. Tourism industry might also face new arrangements for international travel. People might, for example, only allowed to travel if they are below 25 years of age, proven immune to Covid-19 or accept to spend 14 days under quarantine upon arrival.

\footnotetext{
* Corresponding author: mariposa-bonita@yandex.ru
} 
Being the biggest country in the world, Russia contributes a lot to the sphere of tourism and world economy in general. Covid-19 has changed tourism significantly both globally and inside the country.

The purpose of this study was to identify the influence of restrictions caused by the pandemic on the inner-tourism in Russia.

\section{Materials and methods}

This article will be based on research questions that investigate the topic at hand. The following part is the material review, which links critical analysis on research of previous studies already written with the research questions. The data collected will then be exhibited in this chapter, the results will then be analyzed in the discussion section. There will be a conclusion at the end of the study summarizing all the research work and proposing additional investigation that could be pursued to further understand the phenomenon.

\section{Discussion and results}

In 2019, international tourist arrivals reached 1.5 billion, a 4 per cent increase over 2018, consolidating a ten-year record where tourism grew faster than the world economy as a whole. Domestic tourism added a further 8.8 billion arrivals. The sector generated $\$ 1.5$ trillion in exports and employed one in ten people directly or indirectly. 10

Tourism came to a standstill in mid-March 2020. International tourist arrivals decreased by 56 per cent in the first months of the year, with numbers in May down by 98 per cent. This translates into a loss of nearly $\$ 320$ billion in exports - over three times what was lost during the whole of the 2009 global economic crisis. 11 Forward-looking scenarios point to possible declines in arrivals and receipts from international tourism of 58 per cent to 78 per cent for the whole year depending on the speed of containment of the pandemic, the duration of travel restrictions and the gradual re-opening of borders that has now begun but remains uncertain.

This immense shock could translate into a drop of 850 million to 1.1 billion international tourists and a loss of $\$ 910$ billion to $\$ 1.2$ trillion in export revenues from tourism, putting 100 to 120 million direct tourism jobs at risk.13 This is particularly critical as around 80 per cent of all tourism businesses are MSMEs.

Considerable challenges lie ahead, including the unknown evolution of the pandemic and how consumer confidence will recover. The global economy is projected to contract sharply by 4.9 per cent in 2020, though the outlook is expected to pick up in 2021, according to the International Monetary Fund.

Although countries and international organizations have implemented a range of measures to mitigate the socio-economic impacts of COVID-19 and to stimulate the recovery of tourism, the magnitude of the crisis requires extra efforts and continued support. [1]

Because of tourism's supply linkages in goods and services and its strong multiplier effect, the crisis jeopardises sustainable development in both developed and developing nations.

Estimates suggest tourism's shock could reduce global GDP by $\$ 1.17$ trillion, or 1.5 per cent, in the most optimistic scenario (representing a four-month tourism standstill) and up to $\$ 2.22$ trillion, or 2.8 per cent of GDP, in the scenario of an eight-month standstill. Owing to supply chain linkages, the negative impacts of COVID-19 on the economy can be 
as much as three times the loss of tourism receipts. Unemployment in some countries could rise by more than 20 percentage points. 16

The development of tourism promotes investment and openness to merchandise trade as tourism and its related sectors require a wide range of goods and services - many of which small economies do not have the capacity to produce. In SIDS alone, announced greenfield foreign direct investment (FDI) data for 2015-2019 show that travel, tourism and hospitality projects contributed to more than half of all new investment, compared with 16 per cent in the preceding five-year period.

The COVID-19 crisis is expected to cause a dramatic drop in FDI in 2020 and 2021. Global FDI flows are forecast to decrease by up to 40 per cent in 2020 , from US $\$ 1.54$ trillion in 2019. FDI is projected to decrease by a further 5 to 10 per cent in 2021 . The latest World Investment Report's greenfield FDI data shows that travel, tourism and hospitality projects directly affected by the lockdown are among the most severely hit, particularly accommodation and food service activities (-94 per cent)

Particular emphasis should be placed on the fact that COVID-19 led to a complete halt in air traffic in 2020, when countries declared "lockdowns" and imposed strict restrictions on international travel. This situation has seriously affected the tourism industry, and both the public and private sectors are looking for ways to effectively assess the current situation, adapt and revive tourism.

While the pandemic is not over yet, it is important to better understand tourist behavior in order to improve planning and develop appropriate marketing campaigns. The COVID19 pandemic has proved to be more devastating than previous health crises such as Severe Acute Respiratory Syndrome (SARS) and Middle East Respiratory Syndrome (MERS), resulting in a decline in global tourism development in the long term run.

Existing research suggests that people who already place great emphasis on factors related to health, hygiene and mental health will perceive the current health risk at a much higher level. Thus, hygiene, disinfection, and a reliable health care system at the destination will be important factors in travel decisions.

It cannot be denied that at present the mass media have a huge psychological impact on the subconsciousness, consciousness and the formation of a person's personality as a whole. The role of the mass media is related to their influence on the various stages and distribution of the information flow in society. The flow of information, its distribution and influence in the modern world are so diverse and contradictory that neither an individual nor even a group of specialists can filter it independently, so it is the media that has a strong influence. The mass media today is a fairly powerful tool for influencing the emotional, psychological and social state of people, and the degree of influence on young people - an audience with a vulnerable self-consciousness and a shaky worldview-is the greatest.

It is quite reasonable to believe that, as the most powerful tool of influence, the media has numerous functions of influence and influence, which allows us to present only the most common opinions, highlighting both positive and negative factors of media influence. For example, there are "direct" aspects that are related to the main function of the media-the transmission of information: entertainment, informative, educational function, etc.

The works of Professor of Linguistics at the Massachusetts Institute of Technology A. N. Chomsky on the methods of mass management of people are interesting. Even after a cursory study of his research, we understand that carefully thought-out propaganda is the result of the thoughts and intentions of the powerful. Such a powerful weapon is primarily possessed by the mass media. In the practice of mass media today, methods of subconscious influence are widely used, when the attitude of society to certain phenomena of the surrounding world is formed using various methods that are introduced into the news stream, automatically causing in the mass consciousness either a negative or positive reaction to a particular event - the "herd instinct". 
We should pay attention to a new element that differentiates COVID-19 from previous pandemics: how the media, communication and social media, and travel blogs can influence people's intentions to make plans for future travel. This could potentially lead to overreaction, public fear and pessimism.

For example, the discriminatory labeling of COVID-19 as a "China virus" in mainstream media and social media has led to physical attacks on people of Chinese descent and negatively affected the mental health of Chinese travelers as well as their travel intentions [2].

Thus, in addition to people's desire to protect themselves from health risks, the media also plays an important role in influencing their decision to travel and their travel behavior. Understanding these factors and their impact is key to the recovery and growth of the tourism industry.

This study proposes a theoretical model based on the well-known theory of prevention motivation. It has two main factors: pre-travel health behavior and travel media involvement.

Health behavior is measured by three sub-factors - hygiene, physical health, and mental health - while media engagement is measured by the media, social media and targeted websites.

The general behavioral model developed by the researchers suggests that the perception of health risks by tourists and the information obtained from the media - jointly affect the perceived image of the destination.

The impact of the pandemic crisis on domestic tourism was not as disastrous as in the case of foreign travel. On the contrary, according to KupiBilet, Russia ranks second in the world in terms of restoring domestic tourism. The decline in demand was observed in October - by quite acceptable $17 \%$. Among the government's measures to support the industry is the introduction of cashback for domestic tours.

Most hotels closed during the quarantine, so the demand for short-term rental housing increased by $50 \%$ compared to previous years. During the summer season, Russians mainly visited the Crimea, the resorts of the Krasnodar Territory and the Altai. There is a demand for new destinations - Dagestan, Karelia, Ingushetia and the Kaliningrad Region.

Due to the increased interest in domestic tourism, the share of tours sold decreased. People now prefer to travel by choosing their own place of residence. The demand for the service of local guides increased by $46.3 \%$, according to the statistics of Avito Services. At the same time, preferences have shifted from hotel accommodation to daily apartment rentals - it is cheaper and more comfortable.

Among the tourists traveling in Russia, in 2020, residents of large cities who preferred foreign holidays before the pandemic prevailed. Preference was given to sports and educational routes. In the future, this will have a positive impact on the development of the local tourist infrastructure.

A notable trend is that tourists now prefer to travel by car. The car allows you to drive along a complex and interesting route, and in the conditions of quarantine, traveling by private transport is safer than a train or plane. The popularity of motorhomes has increased dramatically: according to Avito Auto, the demand for" motorhomes " has increased by $40 \%$.

Restrictions on mass entertainment events, introduced in Moscow and St. Petersburg, were not slow to affect the winter holidays. Traditionally, Russians like to spend winter holidays in the capitals. Now the direction has changed - tourists, including residents of the capital, go to the regions: Sochi, Sheregesh (Kemerovo), Elbrus, Altai, Karelia, along the route "Golden Ring".

All trends and statistics suggest that 2021 will also be the year of domestic tourism. Many Russians traveled to the country for the first time in 2020, and only because the 
borders were closed. However, many travelers liked the unusual internal routes. According to Raiffeisenbank, 74\% of Russians are ready to spend their holidays in the country if they are told about new interesting places.

Tourists who used to choose luxury destinations, now relax in Russian resorts. This automatically caused an increase in the quality of offers on the market. In the winter season in Sochi, for example, there were premium class taxis, "daily rent" apartments with elite repairs and furnishings.

In general, the increase in demand will cause an increase in prices in middle-class resorts. The head of Alean notes that prices have already increased by $10 \%$, and most likely, the final level of price increase by the summer season of 2021 will be $25-30 \%$.

Many companies have retained the remote mode of operation in 2021 - this also contributes to the development of internal tourist infrastructure. People can work from any locality, which will have a positive effect on short trips that do not interrupt the schedule of remote work. For such a mini-vacation, travelers prefer daily apartments, rather than hotels: it is more convenient to work.

In the summer of 2020, Russia partially opened its borders, and tourists were able to travel to Turkey, Croatia and Montenegro. However, the majority of active travelers still chose to stay in Russian resorts-Turkey took only the fifth place in the number of visits after domestic destinations.

In autumn, flights to Serbia, Ethiopia, Tunisia, and Egypt resumed - but the opening of the borders provoked a new wave of coronavirus infections, and Russian tourists still preferred home recreation. Winter European resorts are still buried for Russians.

Due to the new round of the viral crisis, the rules for entering the most hospitable country for Russians - Turkey-have become more complicated. Starting from December 28, a PCR test made no later than 72 hours ago must be presented at the entrance

Another restriction applies to tourists who have already visited the UK, South Africa or Denmark before arriving in Turkey - travelers will have to undergo a 10-day mandatory quarantine. It is more difficult to spend a vacation in Thailand: although from January 4, Aeroflot and S7 sell air tickets to the country, tourists must pass a 16-day quarantine after arrival.

The world tourism has been pushed back 30 years to the level of 1990, the United Nations World Tourism Organization (UNWTO) is sad to admit. Representatives of the Russian Union of Travel Industry believe that the situation will not change until the end of the second half of 2021 - most European countries will be closed, but even after the full opening of the borders, a rapid recovery in demand should not be expected. Psychological barriers will continue to hold back the flow of tourists abroad - at least until the beginning of 2022.

In addition to the fear of infection, mass tourism in 2021 will be constrained by sanitary restrictions and measures, and as a result-an increase in prices for the service. Hotels and restaurants are raising their price tags because they spend much more on sanitation than they did before the pandemic. In addition, there are rules for limiting the number of guests [3].

The $72 \%$ decline in international tourism in 2020 is due to travel restrictions, travel concerns, and the global struggle to contain the coronavirus. All this led to the fact that this year was the worst in the history of tourism. From January to October, the countries of the world received 900 million fewer tourists than in the same period of 2019. The industry's losses will reach $\$ 1.1$ trillion - the UNWTO states. However, some markets, such as the United States, Germany and France, have recently shown signs of recovery. The demand for domestic tourism continues to grow in Russia, China and some other countries.

Tourism will recover slowly, according to UNWTO. It will return to the doc-like indicators in the best case in 2.5 years, in the worst-in four. 
International tourist flows in the current crisis decreased by 7.5 times more than under the influence of the most powerful recession of 2008.

According to the Federal Tourism Agency, recently announced by its head Zarina Doguzova, the drop in outbound and inbound tourism will reach $80-85 \%$. If we look at the turnover of the entire tourism industry, this year the amount will be reduced by $60 \%$, from 3.7 trillion (in 2019) to 1.6 trillion rubles. At the same time, the domestic tourist flow should be at least $60 \%$ of last year's [4].

According to Rosstat, the income of collective accommodation facilities (hotels, hotels and others) for 9 months of 2020 amounted to 269 billion rubles, or $60 \%$ of the figures of January-September last year (445 billion rubles). The revenues of health resort organizations for the first 9 months of 2020 amounted to 69 billion rubles, which is $65 \%$ of the figures for the same period last year [4-6].

The number of citizens, according to the statistical office, placed in all Russian hotels for 9 months of this year amounted to 28.2 million people, compared to 46.5 million for the same period last year (about 61\%). Over the same period, 2.3 million foreign citizens were placed, and last year -7.7 million, that is, a drop of $70 \%$ [7].

Experts from Intourist and TUI Group believe that Turkey, the United Arab Emirates, Egypt, Maldives, Cuba, Tunisia and Thailand will be the leaders in 2021 - especially if the quarantine rules are relaxed. Demand for the Dominican Republic, Morocco and Greece will also increase. If Spain, France and Italy open their borders to Russian tourists, then trips to these countries will also be in demand $[8,9]$.

A representative of the TUI Group notes a twofold decrease in demand for early booking of tours: so far, most of the applications for the summer of 2021 consist of trips postponed from 2020. Tourists make new reservations cautiously, assuming that vaccination will solve the problem with the risk of infection by the summer season of 2021 - there are practically no applications for earlier dates [10,11].

The rules for entering certain countries are constantly changing-hence the increase in last-minute ticket purchases. Previously, travelers paid for tours and tickets several weeks or even months before the trip.

Industry experts predict an increase in demand for "recovery after covid": resorts will be popular, where you can improve your health, already damaged by the virus, as well as strengthen the immune system, if the disease has so far been avoided.

Remote mode of operation will increase the demand for the "hotel office" format: longterm accommodation, assistance in child care, a comfortable environment in the room - a work desk, additional office devices, high-speed Internet, ergonomic chairs.

Obviously, quarantine restrictions will have an impact on the industry in the long term. The infrastructure of domestic tourism and air traffic will continue to develop. Travel agencies will make every effort to personalize and digitalize services that are global market trends in 2021 [12].

Perhaps the most discussed and expected event of the next year is the launch of a new national project "Tourism and the Hospitality industry". It is designed for 2021-2030, and the planned budget should be 629 billion rubles.

In September last year, the Strategy for the Development of Tourism in the Russian Federation until 2035 was adopted. It was approved by Prime Minister Dmitry Medvedev. The activities and key indicators of this strategy, which Rosturizm has been engaged in for a long time, have migrated to the national project. Apparently, the scale of the goals and objectives set in the strategy led the creators of the document to the idea that it would not be possible to do this within the existing structure and powers of the Federal Tourism Agency, as well as the mechanism of budget funds allocated to it. After all, the financing of projects, the quality of their implementation, and the human resources potential should increase many times [13]. 
Therefore, first, in June 2020, Rosturizm was removed from the Ministry of Economic Development of the Russian Federation and became directly subordinate to Deputy Prime Minister Dmitry Chernyshenko. The activity of the deputy chairman of the government in charge of tourism, his "struggle", was even noted by President Vladimir Putin at his annual press conference, saying that a separate structure would be created for the development of domestic tourism. "People say: it is beautiful, but there is no toilet, neither to pass, nor to pass," the head of state shared his thoughts with journalists. He also cited the example of Turkey and South Korea, where in a few years they have created an excellent infrastructure for recreation.

As it turned out, the tourism corporation will be created on the basis of "Resorts of the North Caucasus", "Corporation for the Development of the North Caucasus" and the fund "Visit the Caucasus". According to the magazine "Rest in Russia" on December 18, "Corporation Tourism.RF" was registered. It was headed by Sergey Sukhanov, who was previously the vice-president of the "Sochi-2014 Organizing Committee" for the preparation of Olympic facilities and infrastructure. The president of the Sochi 2014 Organizing Committee was Deputy Prime Minister Dmitry Chernyshenko. It has already been announced that the new corporation will participate in major investment projects and will develop master plans for tourism clusters.

It is planned that in the new national project, as in the matryoshka doll, there will be three federal projects

The first: "Development of tourist infrastructure and creation of high-quality tourist products". In it, state support measures will include subsidizing the interest rate for the construction of hotels; grant support for public and business initiatives; subsidies to the regions for providing infrastructure and for the formation of tourist-attractive city centers.

Second project: "Increasing accessibility and awareness of tourism products". In it, the support measures include already developed mechanisms: subsidizing trips to citizens (cashback), subsidizing charters, tour operators, co-financing events and promotion.

The third project "Improving Tourism Management" contains such innovations as: the creation of an UNWTO training center and a specialized institute for tourism on the basis of an existing university; the creation of business incubators and accelerators; the transfer of public services by Rostourism to a digital format, improving data collection and statistical accounting; the development and launch of digital solutions aimed at protecting consumer rights, increasing the transparency of the industry; the formation of a national project management system, including a departmental project office; reducing the VAT rate and other support measures $[14,15]$.

The concept of tourist macro-territories with popular tourist "magnets" and existing tourist flows, such as the "Big Ural", "Big Altai", "Big Golden Ring", "Big Volga", the Caucasus, Baikal, etc., is also introduced.

The drafters of the national project plan to increase the export of travel services by 2 times, jobs - by 1.8 times, and the growth of domestic travel - by 2.2 times by 2030 .

Rosturizm has already started collecting applications and proposals from the regions that can be included in the national project.

In addition, to solve the problems of promoting recreation in Russia, it is planned to create the "Tourism Development", the founder of which will be Rosturizm. 1.3 billion rubles should be allocated for its events next year.

It should be noted that this year the agency has become more active in terms of promotion and advertising of domestic resorts and destinations. Contracts worth tens of millions of rubles were signed through contests and auctions: this includes conducting information campaigns in social networks and on the Internet, creating audio-visual videos, placing materials on advertising structures in Moscow, and promoting resorts. For example, only for the services for conducting an information campaign on Internet portals and on the 
YouTube site in the autumn period of 2020, a contract was signed for 27 million rubles. and for public transport campaign services -30.5 million rubles. Perhaps, on a national scale, these figures are not so great, we have only one "Aeroflot" before the pandemic spent, according to various estimates, at least 1 billion rubles a year on its PR and marketing, but for the eternally "poor" and" deprived " tourism industry, and this money looks like manna from heaven.

Another novelty of this crazy year was the program of the Federal Tourism Agency "cashback for holidays in Russia". This was done for the first time, in a short time, together with the Mir payment system, which acted as a technological partner of the program. Everyone could get a 20\% refund on the Mir card (but not more than 20 thousand rubles) from the cost of a tour of Russia or a hotel room purchased on the world travel website.For this purpose, as much as 15 billion rubles were allocated from the federal budget

According to preliminary data, the Russians purchased tours and accommodation with cashback for 6.5 billion rubles following the results of two "waves" of sales. About 300 thousand people took part in the program. The state returned about 1.2 billion rubles to people for traveling around the country. And although these figures are far from the planned 15 billion, the main thing, according to experts, is that the system worked and had a positive psychological effect. Next year, the program will continue, funds for this purpose have already been reserved, which means that the Mir cards will be even more in demand among Russians.

An unexpected gift to entrepreneurs for the New Year can be called the results of the competition of the Federal Tourism Agency for the provision of subsidies for their tourism projects. Out of 4 thousand applications, 474 winners were selected, who received funds for the implementation of their plans. In total, the government allocated 1.2 billion rubles for the competition, and grants amounted to up to 3 million rubles. According to the head of the department Zarina Doguzova, most of the projects were submitted for the creation of campsites, modular hotels, as well as for equipment for their equipment. Also, many applications were received for the development of new tourist routes and the creation of a barrier-free tourist environment. At the same time, there were also dissatisfied with the results of the competition - participants who did not receive grants. They pointed to a conflict of interest - some of the winners were on the competition committee. The faceless list of winners presented by Rosturizm also did not meet the expectations of the participants of this large-scale undertaking. Unlike the presidential grant competition, which the organizers looked up to, there were no names of projects, no descriptions of them, no goals and objectives. In addition, their implementation within 6 months, three of which are winter, also raises doubts among experts. At the same time, the regional authorities were actively involved in the search for interesting projects and were pleased with the victory of their fellow countrymen at the All-Russian competition. Apparently, the main criterion for the effectiveness of this event will be summing up the results and evaluating the quality of the implementation of the winning projects. If we talk about the selection procedure itself, then, of course, it should become more transparent, and the projects themselves, claiming budget funds, open and accessible to the public and the tourist community [15].

The pandemic and closed borders have hit international travel the hardest. The failure of outbound tourism major tour operators were forced to compensate for more active work on the sale of tours in Russia. Some of them have even launched charter flights to a number of popular regions. So, in July, tours to Buryatia, to Lake Baikal, were organized by the largest international tour operator TUI Russia with the support of the Federal Tourism Agency and the Government of the Republic of Buryatia. Prices for sightseeing package tours started from 40 thousand rubles per person with flights and excursions. The tour operator Anex Tour chose the distant Khakassia for the charter experiment. However, 
cheap flight tickets did not encourage Russians to choose this destination for summer holidays, charters soon had to be canceled and switched to regular flights.

Table 1. TOP-20 regions that have preserved tourists as much as possible in 2020.

\begin{tabular}{|c|c|c|}
\hline № & Name of the subject of the Russian Federation & Points \\
\hline 1 & Moscow region & 119.4 \\
\hline 2 & Federal city Moscow & 118.7 \\
\hline 3 & Federal city Saint Petersburg & 118.4 \\
\hline 4 & Krasnodar Region & 118.1 \\
\hline 5 & Republic of Crimea & 114.5 \\
\hline 6 & Altai region & 108.6 \\
\hline 7 & Primorsky Region & 105.2 \\
\hline 8 & Republic of Tatarstan & 105.1 \\
\hline 9 & Republic of Bashkortostan & 100.7 \\
\hline 10 & Sverdlovsk region & 98.7 \\
\hline 11 & Nizhny Novgorod region & 96.3 \\
\hline 12 & Stavropol Territory & 94.9 \\
\hline 13 & Irkutsk region & 94.4 \\
\hline 14 & Samara region & 94.1 \\
\hline 15 & Novosibirsk region & 93.2 \\
\hline 16 & Chelyabinsk region & 91.4 \\
\hline 17 & Rostov region & 91.2 \\
\hline 18 & Tyumen region & 91.1 \\
\hline 19 & Leningrad region & 89.8 \\
\hline 20 & Perm Region & 88.3 \\
\hline
\end{tabular}

\section{Conclusion}

As travel restarts in some parts of the world, limited connectivity and weak consumer confidence, the unknown evolution of the pandemic and the impact of the economic downturn present unprecedented challenges to the tourism sector. Supporting the millions of livelihoods that depend upon a sector affected by months of inactivity, and building a sustainable and responsible travel experience that is safe for host communities, workers and travellers are the key to accelerating recovery.

This crisis is also an unprecedented opportunity to transform the relationship of tourism with nature, climate and the economy. It is time to rethink how the sector impacts our natural resources and ecosystems, building on existing work on sustainable tourism; to examine how it interacts with our societies and other economic sectors; to measure and manage it better; to ensure a fair distribution of its benefits and to advance the transition towards a carbon neutral and resilient tourism economy. A collective and coordinated response by all stakeholders can stimulate the transformation of tourism, together with economic recovery packages, and investments in the green economy.

The COVID-19 crisis is a watershed moment to align the effort of sustaining livelihoods dependent on tourism to the SDGs and ensuring a more resilient, inclusive, carbon neutral, and resource efficient future

Harnessing innovation and digitalization, embracing local values, and creating decent jobs for all, especially for youth, women and the most vulnerable groups in our societies, should be front and centre in tourism's recovery. It's worth to mention, that the sector needs to advance efforts to build a new model that promotes partnerships, places host people at the centre of development, advances evidence-based policies and carbon neutral investment and operations. 


\section{References}

1. World Tourism Organization (UNWTO), World Tourism Barometer, 18(4) (2020)

2. UNWTO, World Tourism Barometer, 18(3) (2020)

3. Z. Alrawadieh, D. Guttentag, M.A. Cifci, G. Cetin, International Journal of Contemporary Hospitality Management (2020)

4. M. De la Harpe, K. Sevenhuysen, Journal of Tourismology, 6(1), (2020)

5. O.A. Volkonskaya, A.V. Kovalyova, N.V. Petrasheva, E.O. Diatlov, European Research Studies Journal, 21(4), 1013-1020 (2018)

6. S.Y. Pektas, A. Hassan, Journal of Tourismology, 6(1) (2020)

7. H. Seraphin, V.G. Gowreesunkar, M. Platania, Journal of Tourismology, 5(2) (2019)

8. Tengilimoglu, E., \& Hassan, A., Applying Flow Theory to the Online Booking Experience: The Role of Utilitarian and Hedonic Features. Journal of Tourismology, 6(1), 2020 https://doi.org/10.26650/jot.2020.6.1.0010.

9. Tourism Economics (2020). Total Travel Industry Impact. Çevrimiçi: https://www.ustravel.org/ toolkit/covid-19-travel-industry-research, Erişim tarihi: 12.04.2020.

10. Global Sustainable Tourism Council, "The Case for Responsible Travel: Trends and Statistics 2019 by CREST" (2019), https:// www.gstcouncil.org/case-responsibletravel-trends-statistics-2019.

11. O.I. Okhrimenko, I.M. Maltsev, V.V. Rokotyanskaya, M.L. Vilisiva, 3the Modelling of Environmental-Economic Systems, National Academy of Management of Culture and Arts Herald (2018), https://www.elibrary.ru/item.asp?id=37235793

12. S.G. Sheina, A.P. Pirozhnikova, E.A. Priss, IOP Conference Series: Materials Science and Engineering, 698(5) (2019), https://iopscience.iop.org/article/10.1088/1757899X/698/5/055010/meta

13. S. Sheina, E. Shevtsova, A. Sukhinin, E. Priss, E3S Web of Conferences, 33 (2018) https://www.e3s-

conferences.org/articles/e3sconf/abs/2018/08/e3sconf_hrc2018_02064/e3sconf_hrc201 8_02064.html

14. V. Bakhtin, L. Minasyan, Socialogical measure of organized culture disproportion in medical tourism system (2018), https://www.elibrary.ru/item.asp?id=36366692

15. N.A. Bakar, S. Rosbi, International Journal of Advanced Engineering Research and Science (IJAERS), 7(4) (2020) 